\title{
Immunohistochemical localisation of tissue plasminogen activator and urokinase in the vessel wall
}

\author{
$\AA ̊$ LARSSON, B ÅSTEDT \\ From the Department of Oral Pathology, School of Dentistry, and the Department of Obstetrics and \\ Gynaecology, University Hospital, Lund, Sweden
}

SUMMARY Immunoreactive plasminogen activators were studied in tissue sections using a peroxidase method and monospecific antibodies to tissue plasminogen activator produced by a melanoma. Tissue plasminogen activator reactivity was found in skin melanomas and in endothelial and smooth muscle cells of arteries and veins. Vessels of the umbilical cord showed higher reactivity than peripheral vessels. Only faint antiurokinase reactivity was found. By means of the fibrin slide technique, fibrinolytic activity could be shown in peripheral vessel walls but not in the umbilical cord, which suggests that immunoreactivity of tissue plasminogen activator bound to an inhibitor can also be demonstrated. This method may be a useful tool in further studies of tissue plasminogen activator in physiological as well as pathological processes.

Plasminogen is converted into plasmin by two naturally occurring plasminogen activators. The so called tissue plasminogen activator ( $t-P A)$ is probably synthesised and released from the vessel wall into the blood stream..$^{1-3}$ t-PA is also released in cultures of various fetal organs. ${ }^{4}$ Urokinase $^{5}$ is secreted from the kidneys into the urine. ${ }^{6}$ It is secreted in kidney cell cultures ${ }^{8}$ and also in cultures of most human fetal organs. ${ }^{4}$

Malignant tumours produce plasminogen activators, and plasminogen activator released from ovarian carcinoma in culture was the first reported to be immunologically identical to urokinase. ${ }^{9}$ Production of urokinase like plasminogen activators has been found in other tumours as well..$^{10-14}$ In addition, certain melanoma cell lines produce blood tissue like plasminogen activator. ${ }^{15}$ t-PA isolated from malignant melanoma cells had provided sufficient amounts of antigen to raise antibodies against t-PA. ${ }^{4}$

In the present study, using monospecific antibodies againt t-PA and urokinase, we examined the histological localisation of immunoreactive plasminogen activators in skin melanoma and in arteries and veins from human umbilical and peripheral vessels.

Accepted for publication 30 August 1984

\section{Material and methods}

Umbilical cords were obtained at delivery of normal infants and superficial veins were obtained at surgery. Uterine arteries were obtained at hysterectomy. Specimens were also obtained from patients undergoing operations for treatment of malignant melanoma. The specimens were immediately fixed in phosphate buffered $(\mathrm{pH} \mathrm{7.4)}$ formalin $(4 \%)$ in saline (PBS-formalin) for several hours at room temperature and embedded in paraffin. Sections were cut at $5 \mu \mathrm{m}$, dewaxed by xylene, and hydrated before the immunohistological procedure. Umbilical cord and peripheral vessel specimens were also fresh frozen. Sections $10 \mu \mathrm{m}$ thick were taken for examination of fibrinolytic activity according to the method of Todd. ${ }^{16}$

\section{ANTIBODIES TO t-PA}

t-PA was obtained from the culture medium of Bowe's melanoma cell line (cells provided by Dr D Collen) and purified from the medium according to Wallén et al. ${ }^{17}$ Antiserum was raised in a goat by two injections (three weeks apart) of $150 \mu \mathrm{g}$ of purified activator, emulsified with Freund's complete adjuvant. The injections were given subcutaneously at different sites in the back. The antiserum gave one precipitation line with melanoma conditioned cul- 
ture medium in gel diffusion. The melanoma activator showed an immunological reaction identical to that obtained with t-PA purified from human uterine tissue. IgG from the antiserum and normal goat serum was purified by ammonium sulphate precipitation, DEAE-Sephadex chromatography, and Sephadex G-200 gel filtration as described previously. ${ }^{4}$ The IgG completely neutralised plasminogen activator activity in plasma and ordinary euglobulin precipitates. One milligram of IgG completely quenched the activity of $0.07 \mathrm{mg}$ of pure melanoma activator.

\section{ANTIBODIES TO UROKINASE}

Urokinase was obtained from Lövens, Copenhagen, and further purified by p-aminobenzamidineSepharose chromatography. ${ }^{18}$ Low molecular weight (MW 31000 ) and high molecular weight (MW $54000)$ urokinase were separated by gel filtration. ${ }^{19}$ Antiserum against low molecular weight urokinase was raised in a goat as described for t-PA. IgG from the antiserum was prepared in the same way.

\section{IMMUNOHISTOCHEMISTRY}

Phosphate buffered saline (PBS, 0.01 M phosphate, $\mathrm{pH} \mathrm{7.4)} \mathrm{was} \mathrm{used} \mathrm{for} \mathrm{all} \mathrm{washings} \mathrm{and} \mathrm{sera} \mathrm{dilutions.}$ All antisera were diluted in PBS plus $0.25 \%$ Triton $\mathrm{X}-100$ and $0.25 \%$ bovine serum albumin. Antisera to t-PA were used at dilutions of $1 / 50$ to $1 / 2000$ and urokinase antisera at $1 / 25$ to $1 / 1000$. Control sections were incubated with goat non-immune sera or with PBS only. Endogenous peroxidase activity was minimised by treating the sections before incubation with primary antibody with $0 \cdot 15 \% \mathrm{H}_{2} \mathrm{O}_{2}$ in absolute methanol for $30 \mathrm{~min}$. All sections were rinsed with PBS for $6 \mathrm{~h}$ before the first antibody incubation and with PBS plus $0.25 \%$ Triton X-100 for 30 min between each subsequent incubation. Sections were incubated with antisera or control sera in a moisture chamber overnight at $4^{\circ} \mathrm{C}$. This was followed by incubation with rabbit antigoat antiserum (1/50, Dakopatts or Nordic) for $30 \mathrm{~min}$. Then, the sections were incubated with the peroxidase-antiperoxidase (PAP) complex (goat PAP, Dakopatts or Nordic, $1 / 150)$. Peroxidase activity was demonstrated by incubation of the sections with 3'3-diaminobenzidine $\times 4 \mathrm{HCl}(0.06 \% \mathrm{DAB} /$ Sigma in $100 \mathrm{ml}$ of

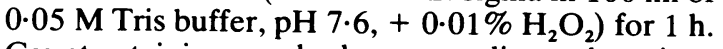
Counterstaining was by haematoxylin, and sections were mounted in Eukitt.

\section{Results}

MALIGNANT MELANOMA

Since our antibody was obtained from a melanoma cell line, we tested a number of different types of melanoma for the presence of t-PA. Heavily pigmented tumours were avoided because the colour of the melanin pigment tended to overlap with the colour of the PAP reaction product. Most melanomas showed a positive $\mathrm{t}-\mathrm{PA}$ reaction at dilutions up to $1 / 500$ to $1 / 1000$. In particular, tumours composed of large, clear epithelioid type cells showed a clear positive reaction in the cell cytoplasm (Fig. 1), whereas variable results were obtained with tumours composed of other types of cells. In sections incubated with antiurokinase, the melanoma cells stained only weakly (not illustrated).

In order to reduce problems of interpreting reactions seen in other tissues (vessel walls etc), we found it essential to include in every separate antit-PA incubation a section of melanoma shown in preliminary studies to be t-PA positive. Hence, for an experimental stain reaction to be regarded as t-PA positive, the accompanying section of melanoma also had to show an unequivocally positive cell reaction, with no reactions in corresponding control sections (Figs. 1 and 2).

\section{ARTERIES AND VEINS}

In sections of umbilical cord, incubated in parallel with melanoma sections showing a positive t-PA reaction, t-PA reactivity was recorded in the endothelium and in the muscle cells of the arterial and venous vessel walls at dilutions of antibody generally lower than those required to show melanoma reactivity (Figs. 3 and 4 ). This reaction was restricted to the cytoplasm of the cells. Staining of the surface cells of the umbilical cord was also seen (cf Fig. 9), but no other stain reaction was found. We did not find any difference in staining intensity between umbilical cord arterial and venous wall cells. Compared with the umbilical cord vessels, a less intense reaction was obtained in peripheral arteries and veins incubated in parallel with the umbilical cord (cf Fig. 9). In these peripheral vessels, both the endothelium and the muscle cells showed a positive t-PA reaction (Figs. 5-8) but only faint staining was seen in sections incubated with antiurokinase (not illustrated).

In frozen sections, incubated for the demonstration of fibrinolytic activity according to Todd, ${ }^{16}$ we were unable to find any activity in the umbilical cord. Clearly visible zones of lysis were present in sections of the peripheral vessels, mainly in the adventitia of the vessel walls. 

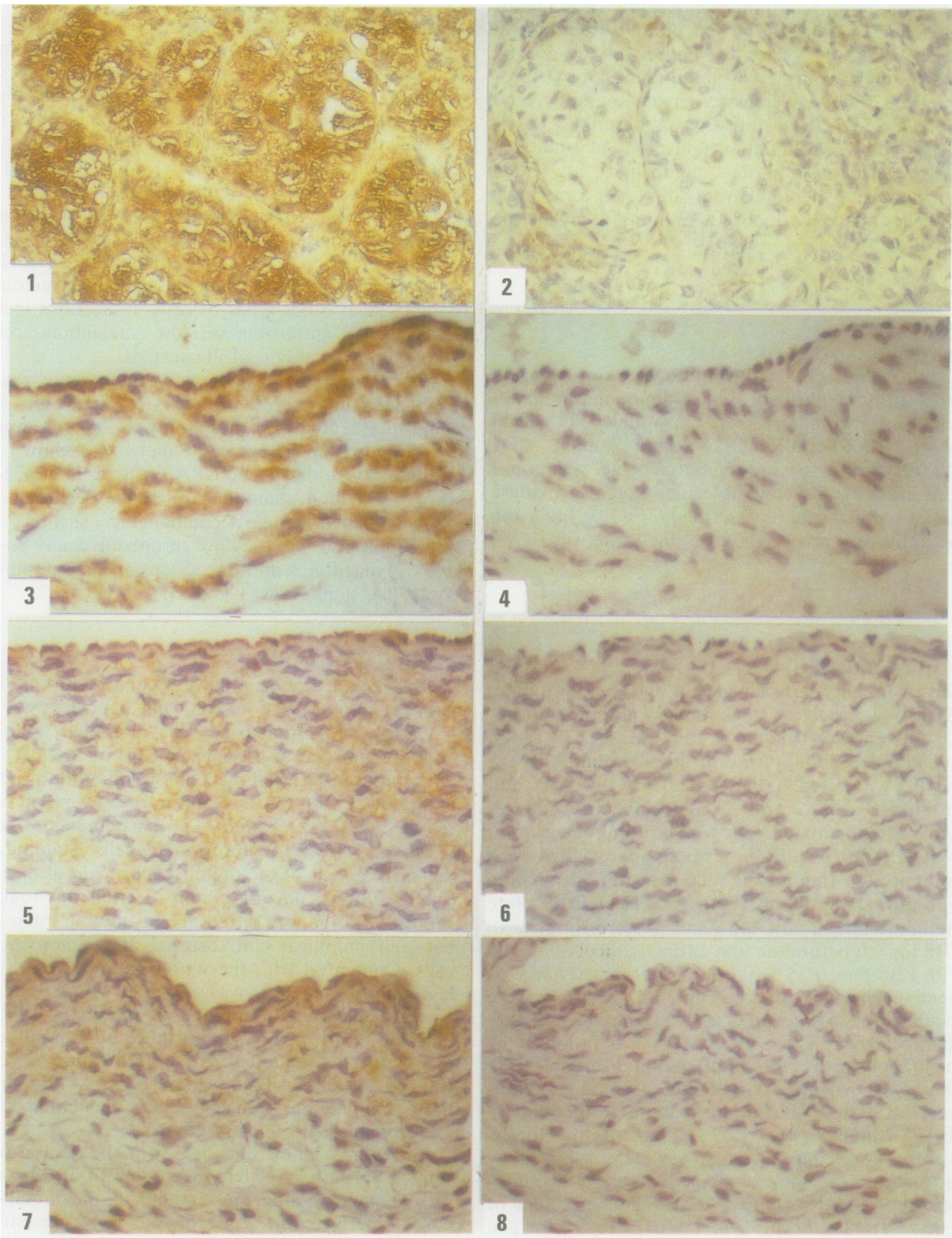
Figs. 1 and 2 Portion of a malignant melanoma of skin, composed of large, clear epithelioid type of cells. Section in Fig. 1 was incubated with anti-t-PA 1/200. Fig. 2 is the control section incubated with non-immune serum. $A$ brown reaction product indicating the presence of $t-P A$ is clearly seen within the cytoplasm of the tumour cells. A brown staining in control sections corresponds to melanin pigment. $\times 400$.

Figs. 3 and 4 Portion of umbilical cord artery, incubated with anti-t-PA 1/80 (Fig. 3). Control section Fig. 4 (see also Fig. 9). Clearly positive staining is found in the endothelium and in the muscle cells. A similar degree of staining was seen in the umbilical cord vein endothelium and muscle cells. $\times 200$.

Figs. 5 and 6 Portion of peripheral artery, incubated with anti-t-PA 1/80 (Fig. 5). Control section Fig. 6 (see also Fig. 9). Positive staining is seen in the endothelium and in the muscle cells, the intensity of staining being less than in corresponding umbilical cord arteries (cf Fig. 3). $\times 200$.

Figs. 7 and 8 Portion of peripheral vein, incubated with anti-t-PA 1/80 (Fig. 7). Control section Fig. 8 (see also Fig. 9). Positive staining is found in the endothelium and in the muscle cells, the intensity being less than in corresponding umbilical cord vein (cf Fig. 3). $\times 200$.

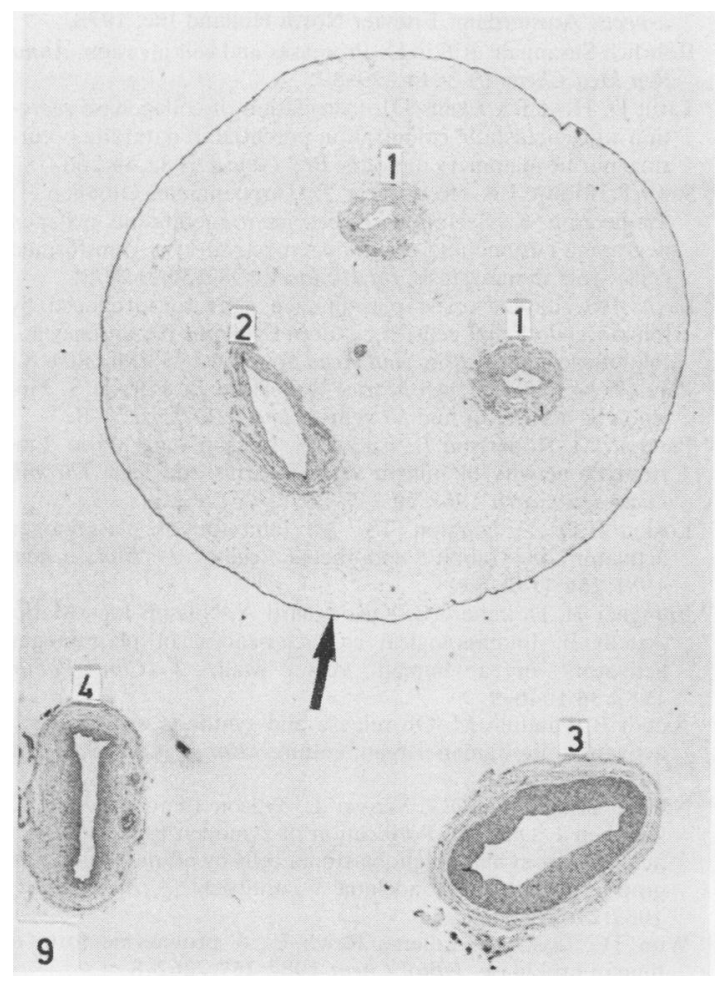

\section{Discussion}

We are unaware of any previous report showing the tissue localisation of immunoreactive plasminogen activator. The published work indicates that proliferating cells, being tumour or embryonal, tend to be appreciable producers of plasminogen activator ${ }^{20-2594}$ In tumours, it has been suggested that the metastatic potential may be related to type IV collagenase activity, due to plasmin activation of the enzyme. ${ }^{2627}$ Our findings are in accordance with the concept of proliferating cell t-PA production. Thus we found that higher dilutions of antibody, indicating greater amounts of t-PA in the cells, could be used to demonstrate melanoma immunoreactivity rather than to demonstrate blood vessel wall reactivity. Also, we found that embryonal cord vessel immunoreactivity was higher than corresponding peripheral blood vessel reactivity. Interestingly, the t-PA immunoreactivity in umbilical cord vessel walls was not associated with any fibrinolytic activity using the Todd technique. In contrast, fibrinolysis was clearly seen in the walls of the peripheral blood vessels. Our findings indicate that the embryonal vessel t-PA is present in a latent form, presumably as an enzyme-inhibitor complex..$^{28}$

To check the validity of the method and the t-PA antibodies, sections of malignant melanomas were used and the presence of t-PA could be clearly identified (Fig. 1). The results also show that in veins as well as in the arteries t-PA is found not only in the endothelium but also in the muscle wall. In several studies using the histochemical method of Todd ${ }^{16}$ as modified by Pandolfi ${ }^{\prime}$ fibrinolytic activity of veins was mainly restricted to the adventitia. ${ }^{29} 30$ I Abscence of endothelial fibrinolytic activity in these studies and the presence of immunoreactive t-PA in the present study may be explained by recent observations that an inhibitor of t-PA is present and released from endothelial cells. ${ }^{231} 28$

We could not completely exclude the presence of urokinase in the vessel walls. Using the histochemical technique, Ljungnér $e a^{32}$ found that the activity of t-PA was completely quenched by antibodies against t-PA but unchanged when antibodies against urokinase were mixed in the fibrin film. It is possible that some enzymatically inactive preurokinase $e^{33-36}$

Fig. 9 Cross section of umbilical cord, with the two arteries (1) and the vein (2), mounted in the same block as a separate peripheral artery (3) and vein (4). In such sections, $t-P A$ reactivity has been recorded in the surface cell layer (arrow), in endothelial cells, and muscle cells of the vessel walls, with umbilical cord vessels showing a higher degree of activity than peripheral vessels (cf Figs. 3-8). $\times 20$. 
which possesses immunoreactive properties could be present in the vessel wall. Holmberg et $a^{4}$, however, found secretion into the medium of $t-P A$ as well as of urokinase in organ culture of various fetal organs, but aorta explants released only t-PA. In cultured human endothelial cells, Levin ${ }^{28}$ did not find any evidence for secretion of urokinase like plasminogen activator.

The method and the results presented here might prove useful for selection of cell structures for culture and production of t-PA and also for experimental studies of t-PA activity in physiological and pathological processes.

This study was supported by grants from the Swedish Medical Research Council (B84-17X-0452310A and B84-24X-06872-01A). The skilful technical assistance of Ms Eva Kreutz is gratefully acknowledged.

\section{References}

' Pandolfi M. Histochemistry and assay of plasminogen activator(s). Eur J Clin Biol Res 1972; 17:254-60.

${ }^{2}$ Loskutoff DS, Edgington TS. Synthesis of a fibrinolytic activator and inhibitor by endothelial cells. Proc Natl Acad Sci USA 1977; 74:3903-7.

${ }^{3}$ Rijken DC, Wijngaards G, Welbergen J. Relationship between tissue plasminogen activator and the activators in blood and vascular wall. Thromb Res 1980; 18:815-30.

${ }^{4}$ Holmberg L, Kristoffersson Ann-Charlotte, Lecander Ingegerd, Wallén P, Åstedt B. Immunoradiometric quantification of tissue plasminogen activator secreted by fetal organs. Comparison with urokinase. Scand J Clin Lab Invest 1982;42:347-54.

5 Astrup T, Sterndorff I. An activator of plasminogen in normal urine. Proc Soc Exp Biol Med 1952;81:675-8.

${ }^{6}$ Ploug J. Kjeldgaard NO. Urokinase, an activator of plasminogen from human urine. I. Isolation and properties. Biochim Biophys Acta 1957;24:278-82.

' Barlow GH. Lazer LaVera. Characterization of the plasminogen activator isolated from human embryo kidney cells: Comparison with urokinase. Thromb Res 1972;1:201-8.

s Åstedt B, Barlow G, Holmberg L. Time-related release of various molecular forms of urokinase in tissue culture. Thromb Res 1977;11:149-53.

, Åstedt B, Holmberg L. Immunological identity of urokinase and ovarian carcinoma plasminogen activator released in tissue culture. Nature 1976;261:595-7.

${ }^{10} \mathrm{Wu}$ M, Arimura GK, Yunis AA. Purification and characterization of a plasminogen activator secreted by cultured human pancreatic carcinoma cells. Biochemistry 1977;16:1908-13.

"Wu MC, Yunis AA. Comparative studies on urokinase and plasminogen activator from cultured pancreatic carcinoma. Int J Biochem 1979; 10: 1001-6.

${ }^{12}$ Naito S, Sueishi K, Hattori F, Tanaka K. Immunological analysis of plasminogen activators from cultured human cancer cells. Virchows Arch (Pathol Anat) 1980;387:251-7.

". Vetterlein D, Bell TE, Young PL, Roblin R. Immunological quantitation and immunoadsorption of urokinase-like plasminogen activators secreted by human cells. J Biol Chem 1980;255:3665-72.
${ }^{14}$ Camiolo SM, Markus G, Evers JL, et al. Plasminogen activator content of neoplastic and benign human prostate tissues; fibrin augmentation of an activator activity. Int $J$ Cancer 1981;27:191-8.

is Rijken DC, Collen D. Purification and characterization of the plasminogen activator secreted by human melanoma cells in culture. J Biol Chem 1981;256:7035-41.

${ }^{16}$ Todd AS. Histological localization of fibrionolysin activator. $J$ Path Bact 1959;78:281-3.

17 Wallén P, Rånby M. Bergsdorf N, Kok P. Purification and characterization of tissue plasminogen activator: on the occurrence of two different forms and their enzymatic properties. In: Davidson JF, Nilsson IM, Åstedt B, eds. Progress in fibrinolysis 1981;5:16-23.

${ }^{18}$ Holmberg L, Bladh B, Åstedt B. Purification of urokinase by affinity chromatography. Biochim Biophys Acta 1976;445:215-22.

${ }^{14}$ Holmberg L, Lecander Ingegerd, Persson B, Åstedt B. An inhibitor from placenta specifically binds urokinase and inhibits plasminogen activator released from ovarian carcinoma in tissue culture. Biochim Biophys Acta 1978;544: 128-37.

:o Astrup T. Fibrinolysis in the organism. Blood 1956;11:781-806.

${ }^{21}$ Peterson HI, Peterson A, Rudenstam CM. Experimental studies on fibrinolysis in growth and spread of tumour. Acta Chir Scand 1968;suppl 394:14-20.

22 Astedt B, Pandolf M. Ontogenesis of tissue plasminogen activator in the human. Thromb Diath Haemorrh 1971;25:469-80.

${ }^{23}$ Svanberg L, Linell F, Pandolfi M, Åstedt B. Plasminogen activators in ovarian tumors. Acta Pathol Microbiol Scand $(A)$ 1975;83: 193-8.

${ }^{24}$ Reich E. Activation of plasminogen: A widespread mechanism for generating localized extracellular proteolysis. In: Ruddon RW, ed. Biological markers of.neoplasia: Basic and applied aspects. Amsterdam: Elsevier North Holland Inc, 1978.

${ }^{2 s}$ Rohrlich Susannah, Rifkin D. Proteases and cell invasion. Annu Rep Med Chem 1979;14:229-39.

${ }^{26}$ Tarin D, Hoyt BJ, Evans DJ. Correlation of collagenase secretion with metastatic-colonization potential in naturally occurring murine mammary tumours. $\mathrm{Br} J$ Cancer 1982;46:266-78.

"7 Salo T, Liotta LA, Keski-Oja J, Turpeenniemi-Hujanen T, Tryggvason $K$. Secretion of basement membrane collagen degrading enzyme and plasminogen activator by transformed cells - role in metastasis. Int J Cancer 1982;30:669-73.

${ }^{28}$ Levin EG. Latent tissue plasminogen activator produced by human endothelial cells in culture: Evidence for an enzymeinhibitor complex. Proc Natl Acad Sci USA 1983;80:6804-8.

${ }^{24}$ Pandolfi M, Nilsson Inga Marie, Robertson B, Isacson S. Fibrinolytic activity of human veins. Lancet 1967;ii:127-8.

${ }^{30}$ Pandolfi M, Robertson B, Isacson S, Nilsson Inga Marie. Fibrinolytic activity of human veins in arms and legs. Thromb Diath Haemorrh 1968;20:247-56.

${ }^{31}$ Loskutof DJ, Edgington TS. An inhibitor of plasminogen activator in rabbit endothelial cells. $J$ Biol Chem 1981;256:4142-5.

${ }^{32}$ Ljungnér $\mathrm{H}$, Holmberg L, Kjaeldgaard A, Nilsson Inga Marie Åstedt B. Immunological characterization of plasminogen activators in a human vessel wall. J Clin Pathol 1983;36: 1046-9.

${ }^{33}$ Åstedt B, Pandolfi M. On release and synthesis of fibrinolytic activators in human organ culture. Eur J Clin Biol Res 1972; 17:261-7.

${ }^{34}$ Nielsen LS, Hansen JG, Skriver L, Wilson Elaine, Kaltoft K, Zeuthen J, Danø K. Purification of zymogen to plasminogen activator from human glioblastoma cells by affinity chromatography with monoclonal antibody. Biochemistry 1982;21:6410-5.

${ }^{3 s}$ Wun TC, Ossowski Liliana, Reich E. A proenzyme form of human urokinase. J Biol.Chem 1982;257:7262-8. 
${ }^{36}$ Levin EG, Loskutoff DJ. Cultured bovine endothelial cells produce both urokinase and tissue-type plasminogen activators. $J$ Cell Biol 1982;94:631-6.
Requests for reprints to: Professor Birger Åstedt, Department of Obstetrics and Gynaecology, University Hospital, S-221 85 Lund, Sweden.

\section{The January 1985 issue}

\section{THE JANUARY 1985 ISSUE CONTAINS THE FOLLOWING PAPERS}

Fine needle aspiration cytology JV LEVER, PA IROTT, AJ WEBB

A monoclonal antibody that detects HLA-D region antigen in routinely fixed, wax embedded sections of normal and neoplastic lymphoid tisues AA EPENETOS, LG BOBROW, TE ADAMS, CM COLLINS, PG ISAACSON, WF BODMER

An immunoperoxidase study of epithelial marker antigens in ulcerative colitis with dysplasia and carcinoma DC ALLEN, JD BIGGART, JC ORCHIN, HEATHER FOSTER

Large bowel mucosal dysplasia and carcinoma in ulcerative colitis DC ALLEN, JD BIGGART, PC PYPER Morphometric assessment of reflux oesophagitis in fibreoptic biopsy specimens LR JARVIS, J DENT, R WHITEHEAD

Argentaffin and argyrophil reactions and serotonin content of endocrine tumours CA WELLS, SM TAYLOR, AC CUELLO

Normal values for the different classes of venous blood mononuclear cells defined by monoclonal antibodies LK GOFF, JA HABESHAW, ML ROSE, JA CRACIE, W GREGORY

Diminished creatinine clearance in anorexia nervosa: reversal with weight gain $F$ BOAG, J WEERAKOON, J GINSBURG, CWH HAVARD, P DANDONA

Plasma fibronectin and thyroid function $W$ GRANINGER, K PIRICH, K DERFLER, W WALDHÄUSL

Sideroblastic colonies in erythroid cultures grown from normal human marrow S KAABA, A JACOBS, $K$ BARNES

SS-A (Ro) antibody in random mother-infant pairs M CALMES, BA BARTHOLOMEW
Cryptosporidiosis in immunocompetent children D ISAACS, GH HUNT, AD PHILLIPS, EH PRICE, F RAAFAT, JA WALKER-SMITH

Gas chromatographic identification of Clostridium difficile and detection of cytotoxin from a modified selective medium PN LEVETT, KD PHILLIPS

Killing of Escherichia coli by human polymorphonuclear leucocytes in the presence of Bacteroides fragilis WAC VEL, F NAMAVAR, AMJJ VERWEIJ-van VUCHT, ANB PUBBEN, DM MacLAREN

Clinical evaluation of a fluorescent antibody test for the serological diagnosis of streptococcal endocarditis DC SHANSON, NICOLA KIRK, R HUMPHREY

Study of precipitation reactions to Actinomyces israelii antigens in uterine secretions ELISABETH PERSSON, $K$ HOLMBERG

Serodiagnosis of ocular toxocariasis: a comparison of two antigens LT GLICKMAN, RB GRIEVE, SS LAURIA, DEBRA L JONES

\section{Technical methods}

Improved gas-liquid chromatography method for the identification of Clostridium difficile JD BERG, RG MILLS, DJ COLEMAN

Demonstration of Mycobacterium tuberculosis in epoxy resin sections by the Ziehl-Neelsen technique KE BRASSIL

Micromodified cytomegalovirus antibody screening test SM HENRY, AM RAMIREZ, DG WOODFIELD

\section{Letters to the Editor}

Book review

Notice

Some new titles

Copies are still available and may be obtained from the PUBLISHING MANAGER, BRITISH MEDICAL ASSOCIATION, TAVISTOCK SQUARE, LONDON WC1H 9JR, price $£ 5 \cdot 00$, including postage. 